\title{
Ants Associated to Loranthaceae in an Agroecosystem Based on Cocoa Trees in Nkolbisson (Yaounde: Cameroon)
}

\author{
Sandrine Jueya ${ }^{1}$, Ruth Mony ${ }^{2} \&$ Champlain Djieto-Lordon ${ }^{2}$ \\ ${ }^{1}$ Laboratoire de Zoologie appliquée, Faculté des Sciences, Université de Ngaoundéré, Cameroun \\ ${ }^{2}$ Laboratoire de Zoologie, Faculté des Sciences, Université de Yaoundé I, Cameroun \\ Correspondence: Ruth Mony, Laboratoire de Zoologie, Faculté des Sciences, Université de Yaoundé I, BP 812 \\ Yaoundé, Cameroun. Tel: 237-699-627-610. E-mail: ruthmony@yahoo.fr
}

Received: February 28, 2019 Accepted: April 9, $2019 \quad$ Online Published: June 15, 2019

doi:10.5539/jas.v11n8p90

URL: https://doi.org/10.5539/jas.v11n8p90

\begin{abstract}
The present study was carried out in order to identify the ant fauna and her potential role as auxiliary of an agricultural system based on cocoa trees leeched by Loranthaceae, in Nkolbisson neighborhood in Yaoundé (Cameroon). The work was conducted from May to September 2015. An inventory of all woody species and the associated ant fauna was carried out beforehand, followed by an inventory of the ant fauna associated couples Theobroma cacao/Loranthaceae during periods of non-flowering, flowering and fruiting Loranthaceae. We inventoried a total of 187 plants of which $44(23.53 \%)$ were parasitized by flowering-shrub epiphytes (Loranthaceae). Theobroma cacao (cocoa) appeared to be the most abundant species (122 plants) followed by Dacryodes edulis (16 safou trees) and Mangifera indica (15 mango trees). Three species of Loranthaceae were identified: Tapinanthus preussii (Engler) Van Tieghem and Phragmanthera capitata (Sprengel) S. Balle which both attack Theobroma cacao (cocoa tree) and Tapinanthus bangwensis (Engl.et. Krause) Denser which attacks mainly forest type trees. Five sub-families of ants (Pseudomyrmicinae, Dolychoderinae, Ponerinae, Formicinae and Myrmicinae) divided into 16 genera and 35 species were recorded throughout the agrosystem. Tetramorium acculeatum has emerged as the most dominant ant species on both T. preussii and P. capitata. Monitoring of the ant foraging activity during flowering and fruiting Loranthaceae shows they participate in the flowers fall.
\end{abstract}

Keywords: Loranthaceae, myrmecofauna, Tetramorium acculeatum, biological control

\section{Introduction}

One critical challenge for plants is to maintain an adequate nutrient supply under fluctuating environmental conditions. This is particularly true for wild and cultivated plants that bear epiphytic species on their branches. The Loranthaceae are shrubs or bushes épiphytoïdes chlorophyll hemiparasites who can cause significant damage in agro-ecosystems. These plants have developed mutualistic and functionally associations with different wild and cultivated host plants that contribute substantially to their mineral nutrition and, thus their fitness and survival when in the other hand, the host plant is declining. Focusing on finding an efficient method of struggle against Loranthaceae, this study was carried out from May to September 2015 in Nkolbisson neighborhood in Yaoundé. The control method mainly based on mechanical suppression of the host parasitized branches appears useless (Dibong et al., 2010). In Cameroon, the Loranthaceae are represented by 26 species distributed in 7 genus (Polhill \& Wiens, 1998; Balle, 1982). This family gathers epiphytic plants that offer nests and nutriments to a great diversity of invertabrates like ants (Acheampong et al., 2013). But in some conditions, they can become true scourges. Their repartition and the lost caused vary (Mony et al., 2009; Dibong et al., 2012).

\section{Material and Methods}

\subsection{Study Site}

The study was carried out from may to september 2015 in an agrosystem based on cocoa trees $\left(3^{\circ} 51^{\prime} 56^{\prime \prime} \mathrm{N}\right.$, $11^{\circ} 27^{\prime} 36^{\prime \prime} \mathrm{E}$ ) of $2400 \mathrm{~m}^{2}$ area, situated at Nkolbisson a peripheric quarter of Yaounde town (Figure 1). This site is subject to a humid and equatorial climate with four seasons: a small rainy season (mi-march to end of june), a small dry season (july to august), a big rainy season (september to half of november), a big dry season (half of November-half of march) (Olivry, 1986). The vegetation is predominated by the meridional humid forest and 
Theobroma cacao L. is the most represented tree in the field eventhough other fruit trees and wild trees are observed.

The inventory carried out at the field enabled the census of all plant species of the area and to classify them into parasitic and not parasitic species. Only host individuals having a DBH (Diameter at Breast Height) $\geq 5 \mathrm{~cm}$ were maintained and Loranthaceae were identified. Counting was done on the number of host parasites and the number of tufts of Loranthaceae present on each tree. These data enabled us to determine the level and the intensity of parasitism in the field.

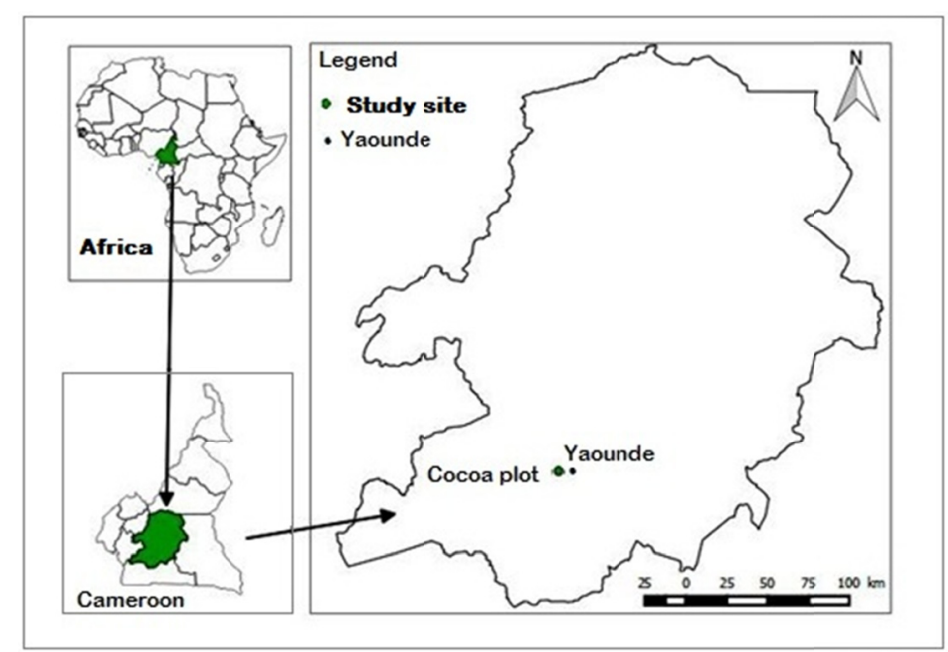

Figure 1. Location map of the study area

\subsection{Flora Inventory}

In order to determine the floristic diversity of the agroecosystem, the study was conducted from may to September 2015. Investigations had been conducted by using $5 \times 5 \mathrm{~m}$ plots, in a parcel of about $2400 \mathrm{~m}^{2}$ surface area. The different trees were marked and identified. By direct observations, all the species of Loranthaceae were identified based on their flower shape and color and counted per species and per host-tree. Only host individuals having a DBH (Diameter at Breast Height) $\geq 5 \mathrm{~cm}$ were maintained and Loranthaceae were identified. Counting was done on the number of host parasites and the number of tufts of Loranthaceae present on each tree. These data enabled us to determine the parasitism prevalence which is the percentage of parasite individuals in the orchard. The intensity of parasitism which expresses the extent of parasitism on parasite individuals in the orchard; it is expressed by the average number of tufts of Loranthaceae observed per individual.

\subsection{Harvesting and Identification of Myrmecofauna}

Before the study of ant foraging activity in the field, an inventory of the whole myrmecofauna of the field has been conducted. The presence or absence of ants was noticed for each tree during $5 \mathrm{mn}$, through the direct observation of active workers. Observations in the field at different times of the day enabled the determination of the period of maximal foraging of different ants on every individual host. Zones of inking were elevated with a cutlass in order to capture the ants in the pores of the individual host. Quadrates of $5 \times 5 \mathrm{~cm}$ were delimited randomly on the host and its parasites in order to harvest all the ants, and counted thus estimating the density of ants. These ants were collected using a mouth aspirator (for workers of medium size), a brush or with the aid of soft pliers for the workers for big workers of big sizes and conserved in labeled boxes containing $70{ }^{\circ} \mathrm{C}$ alcohol and brought to laboratory at the faculty of Science of University of Yaounde 1 for further identification. All the ants observed at the higher of the breast were collected.

For the follow up of the foraging activity of ant workers, we selected 6 cocoa trees ( 3 parasitized by loranthaceae and 3 not parasitized) in order to determine the influence of Loranthaceae in the myrmecofauna distribution. On parasitized cocoa trees the study was extended to leaves, flowers, fruits and suckers of prospected loranthaceae. The experimental design enabled observations from the beginning of floral bud formation right up to the bay passing through flowers that have blossom was put in place. On every host, individual having at least five parasitized tufts of Loranthaceae, three were chosen and on every tuft a small branch was retained. On this 
branch, three nodes were tagged and measurements were taken every other day during the study period in order to count the floral buds, flowers and fruits. These samples were taken both during a period of flowering and fruiting of Loranthaceae, and a period of non-flowering as well. To make it possible, plastic were put under selected trees in order to collect and count the fallen flowers and fruits due to ant foraging activity during all the period of flowering and fruiting of Loranthaceae. Identification of ants has been made possible by the use of the identification keys (Hölldobler \& Wilson, 1990; Bolton, 1994, 2016; Taylor, 2011) based on the morphology. Ants were observed under the classic binocular microscope. A few specimens of each were deposited in the laboratory of Zoology of the University of Yaounde 1.

\subsection{Statistical Analysis}

The percentage of parasitism (Pp) in the field was giving by the following expression $\mathrm{Pp}=$ number of trees infected/total number of trees $\times 100$.

The inventory of both infested and not infested trees in the field enabled to determine the prevalence of Loranthaceae on the three types of considered plants defined as followed: cocoa trees, foresters and fruit trees.

The prevalence $(\mathrm{P})$ is the percentage of infested plants of a particular type of tree over the total number of the plants of the same type of tree:

$$
\mathrm{P}=(\mathrm{na} / \mathrm{Na}) \times 100
$$

where, $n a=$ number of the parasitized plants of type "a"; $\mathrm{Na}=$ total number of the plants of type "a".

The number of suckers beared by each parasitized tree allowed us to determine his parasitic charge.

The inventory and the identification of the number of sucker per species of Loranthaceae enabled to determine the intensity P (\%) of parasitism of every species of Loranthaceae present in the field.

The rate of prevalence of a Loranthaceae species was giving by the following expression:

$$
\mathrm{P}(\%)=(\mathrm{na} / \mathrm{N}) \times 100
$$

where, na is the number of sucker of the Loranthaceae species "a", $N$ the total number of suckers of the three species of Loranthaceae pooled

The correlation existing between the myrmecofauna inventoried and the extent of the flower fall for each studied sucker was given by the software R. version 3.2.3.

\section{Results}

\subsection{Woody Species of the Field}

We inventoried a total of 187 trees distributed into 12 families and 18 species. Plants were grouped into four catégories named cocoa trees, foresters, fruit trees and herbaceous. Those of the foresters that couldn't be identified were represented by their family name or have been given a code. Cocoa trees appeared to be the most abondant (122 plants or $65.2 \%)$, followed respectively by fruit trees (37 or $19.8 \%)$, foresters $(15$ or $8 \%)$ and herbaceous (13 or $7 \%$ ).

By their circumference and heigh, foresters are dominants trees in the field with respectively $161.33 \pm 81.04 \mathrm{~cm}$ and $503.67 \pm 380.18 \mathrm{~cm}$ when Cocoa trees are found to have reduced dimensions, that means $39.43 \pm 11.36 \mathrm{~cm}$ in circumference and $170.91 \pm 72.47 \mathrm{~cm}$ high (see table I).

\begin{tabular}{|c|c|c|c|}
\hline Type of trees $(\mathrm{N}=$ size $)$ & Cocoa trees $(\mathrm{N}=122)$ & Fruit trees $(\mathrm{N}=37)$ & Foresters $(\mathrm{N}=15)$ \\
\hline Mean circumferences (in $\mathrm{cm}$ ) & 39.43 \pm 11.36 (Min: 16; Max: 80) & 121.11 \pm 60.23 (Min: 51; Max: 313) & 161.33 \pm 81.04 (Min : 42; Max: 300) \\
\hline Mean heigh (in $\mathrm{cm}$ ) & 170.91 \pm 72.47 (Min: 24; Max: 410) & 412.16 \pm 234.61 (Min: 101; Max: 1040) & $503.67 \pm 380.18($ Min: $85 ;$ Max: 1200$)$ \\
\hline
\end{tabular}

Table 1. Mean values of trees circumferences and heigh in the field

Note. Min $=$ minimum; Max $=$ maximum.

\subsection{Species of Loranthaceae Inventoried in the Field}

Three species of Loranthaceae have been inventored in the whole field (Figure 2): P. capitata (Sprengel) S. Balle, T. bangwensis (Engl. \& K. Krause) Denser and T. preussii (Engler) Van Teghem. Both P. capitata and T. preussii attack T. cacao (cocoa tree), D. edulis (Safoo tree), S. mombin (Casmanga, fruit tree), and other forester trees; $T$. bangwensis essentially attacks forester trees (Fucus sp., Sizygium cf. jambos, Milicea escelsa). 

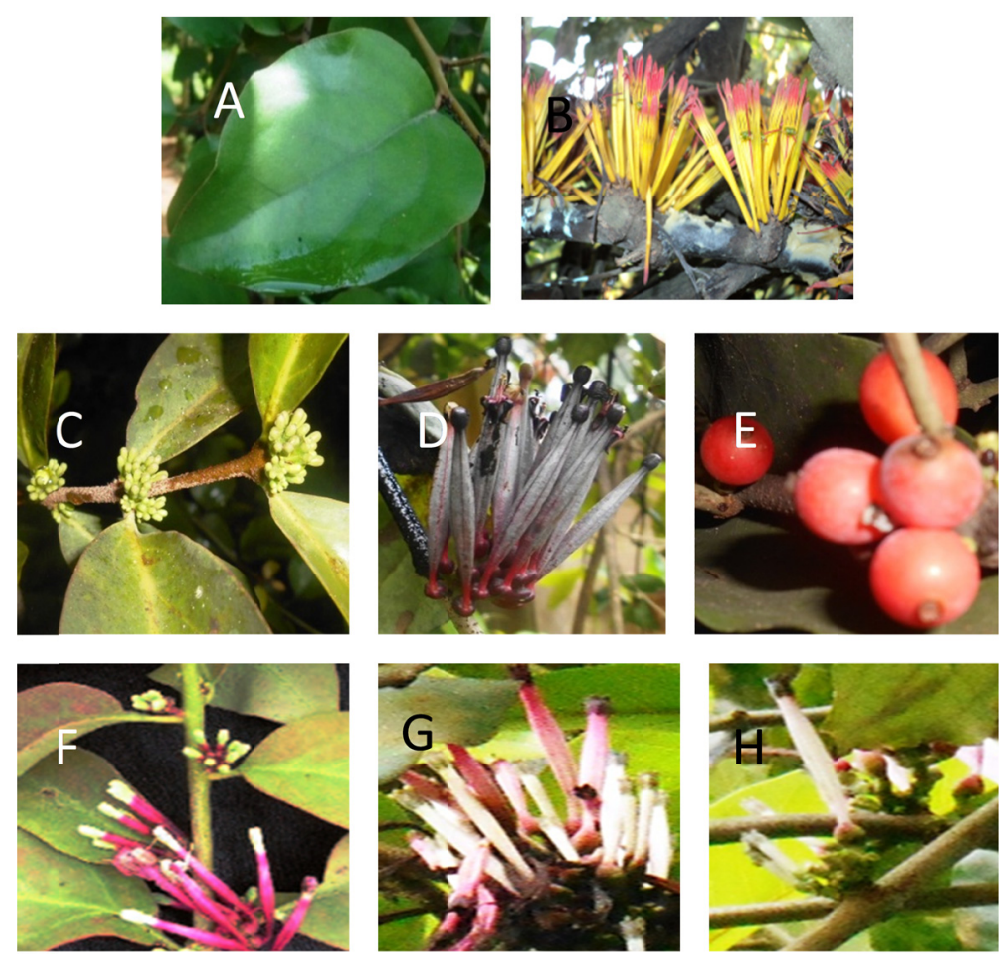

Figure 2. Variety of Loranthaceae recorded in the field: $\mathrm{A}=$ leave of Phragmanthera capitata $; \mathrm{B}=$ mature flowers of P. capitata $; \mathrm{C}=$ the beginning of growth of the floral buds of T. preussii; $\mathrm{D}=$ mature flowers of Tapinanthus preussii $\mathrm{E}=$ Mature fruit of $T$. preussii $; \mathrm{F}=$ the beginning of growth of the floral buds of $T$. bangwansis; $\mathrm{G}=$ mature flowers of $T$. bangwensis; $\mathrm{F}=$ beginning of fructification

\subsection{Parasitism Characterization in the Field}

It varies from one plant to another; $8(53 \%)$ foresters are parasitized when $7(47 \%)$ are healthy; $33(27 \%)$ cocoa trees are infested by Loranthaceae when 34 (92\%) are healthy; none of the herbaceous was parasitized. The Chi-deux $\left(\mathrm{X}^{2}\right)$ test associated to the rate of parasitism depending to the type of plant is highly significant (P-value $=0.007)($ Table 2$)$.

Table 2. Inventory of parasitized and not parasitized trees in the field

\begin{tabular}{llll}
\hline Types of plants & Healthy plants & Parasitized plants & Total \\
\hline Cocoa trees & $89(73 \%)$ & $33(27 \%)$ & $122(100 \%)$ \\
Fruiters & $34(92 \%)$ & $3(8 \%)$ & $37(100 \%)$ \\
Foresters & $7(47 \%)$ & $8(53 \%)$ & $15(100 \%)$ \\
Herbaceous & $13(100 \%)$ & $0(0 \%)$ & $13(100 \%)$ \\
\hdashline$\chi^{2}=18.65 ;$ dd $l=3 ; p$-value $=0.0007$ & & & \\
\hline
\end{tabular}

\subsection{Loranthaceae Species Distribution on the Host Individuals}

The trees in the field are parasitized at different levels; the distribution is as follow: T. preussii appeared to be the most frequent with $64 \%$ of rate of presence in the field trees, followed by P. capitata (33\%) and T. bangwensis present on only $3 \%$ of trees (Figure 3 ). 


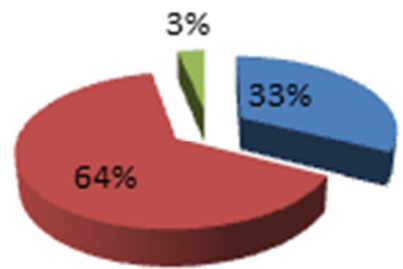

Figure 3. Distribution of different species of Loranthaceae in the field

The parasitic charge can be defined here as the number of suckers beared by a host tree. The forester species Sizyguim cf. jambos L. (Alston) was the most parasitized of all the trees in the field with 46 suckers (15.67\%) over the 272 scored on the three species of Loranthaceae pooled; it was followed by a fruit species Dacryodes edulis (25 suckers, 9.19\%). Parasititized cocoa trees gathered a total of 133 suckers (48.9\%), an average of 4 suckers $(1.48 \%)$ for each parasitized cocoa tree.

Table 3. Percentage of parasitism and parasitic charge per woody parasitized species

\begin{tabular}{|c|c|c|c|c|c|c|}
\hline Families & Species & N.S.P.C. & N.S.T.P. & N.S.T.B. & Parasitic Gharge & $\% \mathrm{~S} / \mathrm{S} / \mathrm{T}$ \\
\hline Anacardiaceae & Spongia mombin & 1 & 4 & 0 & 5 & 1.84 \\
\hline Burseraceae & Dacryodes edulis (G.Don) H.J.Lam & 2 & 5 & 0 & 7 & 9.19 \\
\hline Caesalpinaceae & Caesalpinacea & 2 & 5 & 0 & 7 & 2.57 \\
\hline Forester 1 & Forester 1 & 4 & 2 & 0 & 7 & 2.57 \\
\hline Forester 2 & Forester 2 & 4 & 0 & 1 & 5 & 1.84 \\
\hline Forester 3 & Forester 3 & 1 & 0 & 3 & 4 & 1.47 \\
\hline \multirow[t]{2}{*}{ Maraceae } & Milicea escelsa (iroko) & 8 & 11 & 0 & 19 & 6.98 \\
\hline & Ficus sp. & 8 & 7 & 1 & 16 & 5.89 \\
\hline Musaceae & Persea americana Mill & 3 & 2 & 0 & 5 & 1.84 \\
\hline Myrtaceae & Sizyguim cf. jambos & 37 & 5 & 4 & 46 & 16.91 \\
\hline \multirow[t]{2}{*}{ Sterculiaceae } & Theobroma cacao L. & 3 & 130 & 0 & 133 & 48.9 \\
\hline & Total & $81(30 \%)$ & $181(67 \%)$ & $9(3 \%)$ & $272(100 \%)$ & 100 \\
\hline
\end{tabular}

Note. N.S.P.C. $=$ Number of suckers of P. capitata ; N.S.P.P. $=$ Number of suckers of $T$. Preussii $;$ N.S.T.B. $=$ Number of suckers of T. Bangwensis; \% S/S/T = Pourcentage of suckers per species of tree

\subsection{Inventory of Myrmecofauna}

A total of 35 ants species belonging to 16 genera and 5 sub-families were collected. It appeared that the Myrmicinae sub-family is the most diversified followed by the Formicinae. The Pseudomyrmicinae is the less represented sub-family. In Myrmicinae sub-family, the genus Tetramorium Mayr, (1855) was the most abundant followed by the genus Pheidole Westwood, 1839.The sub-family Dolichoderinae although poorly diversified, revealed a high numeric abundance by the presence of the genus Tapinoma Förster (1850). The mymecofauna of the field was dominated by the species Tetramorium aculeatum Mayr, 1866 (64.71\% of the total myrmecofauna), Pheidole megacephala Fabricius, 1793 (17.2\%) and Tapinoma sp. (10.1\%). As a function of the type of plant, the myrmecofauna of the field has been distributed in sub-families and species as indicated in table IV. 
Table 4. Myrmecofauna associated to different plant species in the agrosystem of Nkolbisson

\begin{tabular}{|c|c|c|c|c|c|c|}
\hline Sub-families & Species & Cocoa trees & Foresters & Fruit trees trees & Herbaceous & Total \\
\hline \multirow{4}{*}{ Dolichoderinae } & Axinidris bidens Shattuck, 1991 & $1(0.05 \%)$ & 0 & 0 & 0 & $1(0.04 \%)$ \\
\hline & A. hypoclinoïdes (Santschi) 1919 & $1(0.05 \%)$ & 0 & 0 & 0 & $1(0.04 \%)$ \\
\hline & Tapinoma sp. & $17(8.65 \%)$ & $9(7.7 \%)$ & $88(17.6 \%)$ & $2(2.7 \%)$ & $272(10.1 \%)$ \\
\hline & Technomymex sp. & $4(0.2 \%)$ & 0 & 0 & 0 & $4(0.15 \%)$ \\
\hline \multirow{11}{*}{ Formicinae } & Acropyga sp. & $1(0.05 \%)$ & 0 & 0 & 0 & $1(0.04 \%)$ \\
\hline & Lepisiota guineensis Mayr, 1902 & $1(0.05 \%)$ & 0 & 0 & 0 & $1(0.04 \%)$ \\
\hline & Polyrhachis aenescens Stitz, 1910 & 0 & 0 & $1(0.2 \%)$ & 0 & $1(0.04 \%)$ \\
\hline & P. decemdentata Andre, 1889 & $2(0.1 \%)$ & 0 & $1(0.2 \%)$ & 0 & $3(0.11 \%)$ \\
\hline & P. laboriosa Smith, 1858 & $1(0.05 \%)$ & 0 & 0 & 0 & $1(0.04 \%)$ \\
\hline & P. militaris Fabricius, 1782 & 0 & 0 & 0 & 0 & 0 \\
\hline & Camponotus acvapimensis Mayr, 1862 & $3(0.15 \%)$ & $2(1.7 \%)$ & 0 & $1(1.4 \%)$ & $6(0.23 \%)$ \\
\hline & C. bayeri Forel, 1913 & $1(0.05 \%)$ & $1(0.8 \%)$ & 0 & 0 & $2(0.07 \%)$ \\
\hline & C. brutus Forel, 1886 & $4(0.2 \%)$ & 0 & 0 & 0 & $4(0.15 \%)$ \\
\hline & C. flavomarginatus Mayr, 1862 & $4(0.2 \%)$ & 0 & $1(0.2 \%)$ & $3(4 \%)$ & $8(0.3 \%)$ \\
\hline & C. vividus Smith, 1858 & $1(0.05 \%)$ & 0 & 0 & 0 & $1(0.04 \%)$ \\
\hline \multirow{14}{*}{ Myrmicinae } & Atopomyrmex mocquerysi Bolton, 1981 & 0 & 0 & $2(0.4 \%)$ & 0 & $2(0.07 \%)$ \\
\hline & Cataulacus centrurus Bolton, 1982 & $1(0.05 \%)$ & 0 & 0 & 0 & $1(0.04 \%)$ \\
\hline & C. erinaceus Stitz, 1910 & $1(0.05 \%)$ & 0 & 0 & 0 & $1(0.04 \%)$ \\
\hline & C. guineensis Smith, 1853 & $19(0.94 \%)$ & $4(3.4 \%)$ & $7(1.4 \%)$ & $1(1.4 \%)$ & $31(1.15 \%)$ \\
\hline & C. kloli Mayr, 1895 & $47(2.3 \%)$ & $5(4.3 \%)$ & $1(0.2 \%)$ & 0 & $53(1.9 \%)$ \\
\hline & C. mocquerysi Andre, 1889 & $6(0.31 \%)$ & 0 & $3(0.6 \%)$ & 0 & $9(0.3 \%)$ \\
\hline & C. pymaeus Andre, 1890 & $22(1.1 \%)$ & $24(20.5 \%)$ & $12(2.4 \%)$ & $3(4 \%)$ & $61(2.3 \%)$ \\
\hline & C. weissi Santschi, 1913 & $3(0.15 \%)$ & $1(0.8 \%)$ & $3(0.6 \%)$ & 0 & $7(0.27 \%)$ \\
\hline & Myrmicaria stiatula Santschi, 1925 & 0 & 0 & 0 & $1(1.4 \%)$ & $1(0.04 \%)$ \\
\hline & P. megacephala (Fabricius), 1793 & $396(19.8 \%)$ & $21(18 \%)$ & $33(6.6 \%)$ & $14(19.1 \%)$ & $464(17.2 \%)$ \\
\hline & P. tenuinodis Mayr, 1901 & 0 & 0 & 0 & 0 & 0 \\
\hline & T. aculeatum (Mayr), 1866 & $1304(65.1 \%)$ & $49(42 \%)$ & $342(68 \%)$ & $49(66 \%)$ & $1744(64.71 \%)$ \\
\hline & T. angulinode Santschi, 1910 & $2(0.1 \%)$ & 0 & 0 & 0 & $2(0.07 \%)$ \\
\hline & T. sericeiventre Emery, 1877 & $1(0.05 \%)$ & 0 & $2(0.4 \%)$ & 0 & $3(0.11 \%)$ \\
\hline \multirow{4}{*}{ Ponerinae } & Leptogenys elegans Bolton, 1975 & $1(0.05 \%)$ & 0 & $1(0.2 \%)$ & 0 & $2(0.07 \%)$ \\
\hline & Anochetus bequaerti Forel, 1913 & 0 & 0 & $1(0.2 \%)$ & 0 & $1(0.04 \%)$ \\
\hline & Anochetus sp.1 & $1(0.05 \%)$ & 0 & 0 & 0 & $1(0.04 \%)$ \\
\hline & Anochetus sp. 2 & $1(0.05 \%)$ & 0 & 0 & 0 & $1(0.04 \%)$ \\
\hline \multirow{3}{*}{ Pseudo myrmicinae } & Tetraponera s.s. & $1(0.05 \%)$ & $1(0.8 \%)$ & $2(0.4 \%)$ & 0 & $4(0.15 \%)$ \\
\hline & T. anthracina (Santschi), 1910 & 0 & 0 & 0 & 0 & 0 \\
\hline & Total & $2003(100 \%)$ & $117(100 \%)$ & $500(100 \%)$ & $74(100 \%)$ & $2694(100 \%)$ \\
\hline
\end{tabular}

\subsection{Myrmecofauna Distribution on Selected Parasitized and Not Parasitized Cocoa Trees}

Cocoa trees that beared Loranthaceae presented a more abundant and diversified myrmecofauna (2204 ants) compared to not parasitized trees $(1343$ ants $)\left(\chi^{2}=209 ; \mathrm{ddl}=1 ; \mathrm{P}\right.$-value $\left.=2.2 \times 10^{-16}\right)($ Table 5$)$. 
Table 5. Myrmecofauna diversity and abundance associated to parasitized and non parasitized cocoa trees

\begin{tabular}{llll}
\hline Species of ants & Parasitized cocoa trees & Not parasitised cocoa trees & Total \\
\hline Tetraponera anthracina & $2(0.09 \%)$ & 0 & $2(0.06 \%)$ \\
Atopomyrmex mocquerysi & $1(0.05 \%)$ & 0 & $1(0.03 \%)$ \\
Camponotus acvapimensis & $1(0.05 \%)$ & $1(0.07 \%)$ & $2(0.06 \%)$ \\
Camponotus bayeri & $1(0.05 \%)$ & 0 & $1(0.03 \%)$ \\
Camponotus brutus & 0 & $3(0.2 \%)$ & $3(0.08 \%)$ \\
Camponotus flavomarginatus & $6(0.3 \%)$ & $1(0.07 \%)$ & $7(0.2 \%)$ \\
Cataulacus guineensis & 0 & $1(0.07 \%)$ & $1(0.03 \%)$ \\
Cataulacus mocquerysis & $16(0.7 \%)$ & 0 & $16(0.5 \%)$ \\
Cataulacus pymaeus & $14(0.6 \%)$ & 0 & $14(0.4 \%)$ \\
Leptogenys elegans & $1(0.05 \%)$ & 0 & $1(0.03 \%)$ \\
Myrmicaria stiatula & $1(0.05 \%)$ & $2(0.1 \%)$ & $3(0.08 \%)$ \\
Pheidole megacephala & $3(0.13 \%)$ & $840(62.5 \%)$ & $843(23.8)$ \\
Pheidole tenuinodis & $2(0.09 \%)$ & 0 & $2(0.06 \%)$ \\
Polyrachis aenescens & 0 & $2(0.1 \%)$ & $2(0.06 \%)$ \\
Polyrachis decemdentata & $5(0.2 \%)$ & $1(0.07 \%)$ & $6(0.17 \%)$ \\
Polyrachis militaris & 0 & $1(0.07 \%)$ & $1(0.03 \%)$ \\
Tapinoma sp. & $279(12.7 \%)$ & $290(21.6 \%)$ & $569(16 \%)$ \\
Tetramorium acculeatum & $1869(84.8 \%)$ & $201(15.15 \%)$ & $2070(58.3 \%)$ \\
Tetramorium angulinode & $3(0.143 \%)$ & 0 & $3(0.08 \%)$ \\
Total & $2204(100 \%)$ & $1343(100 \%)$ & $3547(100 \%)$ \\
\hline
\end{tabular}

\subsection{Ant distribution Depending on Species of Loranthaceae}

Considering all the flowers collected on every sucker, it appears that the fall of flowers is more important on young ones with a total of 1851 (non opened flowers) than on the old ones with 212 opened flowers. Ants proceed to the mechanic castration of young flowers and hence to the low production of fruits. So we have collected respectively from the sucker $\mathrm{S}_{112-2}, 1013$ ants for 2063 fallen flowers (non opened and opened ones); 767 ants for 551 fallen flowers in Sucker $\mathrm{S}_{63} ; 446$ ants for 451 fallen flowers in $\mathrm{S}_{88}$ and 257 ants for 211 fallen flowers in sucker $\mathrm{S}_{112-1}$. T. aculeatum is the most abundant species of all the suckers. The correlations between the number of ants and the number of fallen flowers depending on the selected suckers were realized in table VI:

Table 6. Correlation coefficient per Loranthaceae followed

\begin{tabular}{lllll}
\hline Suckers & $\mathbf{S}_{\mathbf{1 1 2}-\mathbf{1}}$ & $\mathbf{S}_{\mathbf{1 1 2 - 2}}$ & $\mathbf{S}_{\mathbf{8 8}}$ & $\mathbf{S}_{\mathbf{6 3}}$ \\
\hline Spearman correlation coefficient values (rho) & 0.29 & 0.05 & 0.38 & 0.37 \\
P-value & 0.27 & 0.85 & 0.13 & 0.15 \\
\hline
\end{tabular}




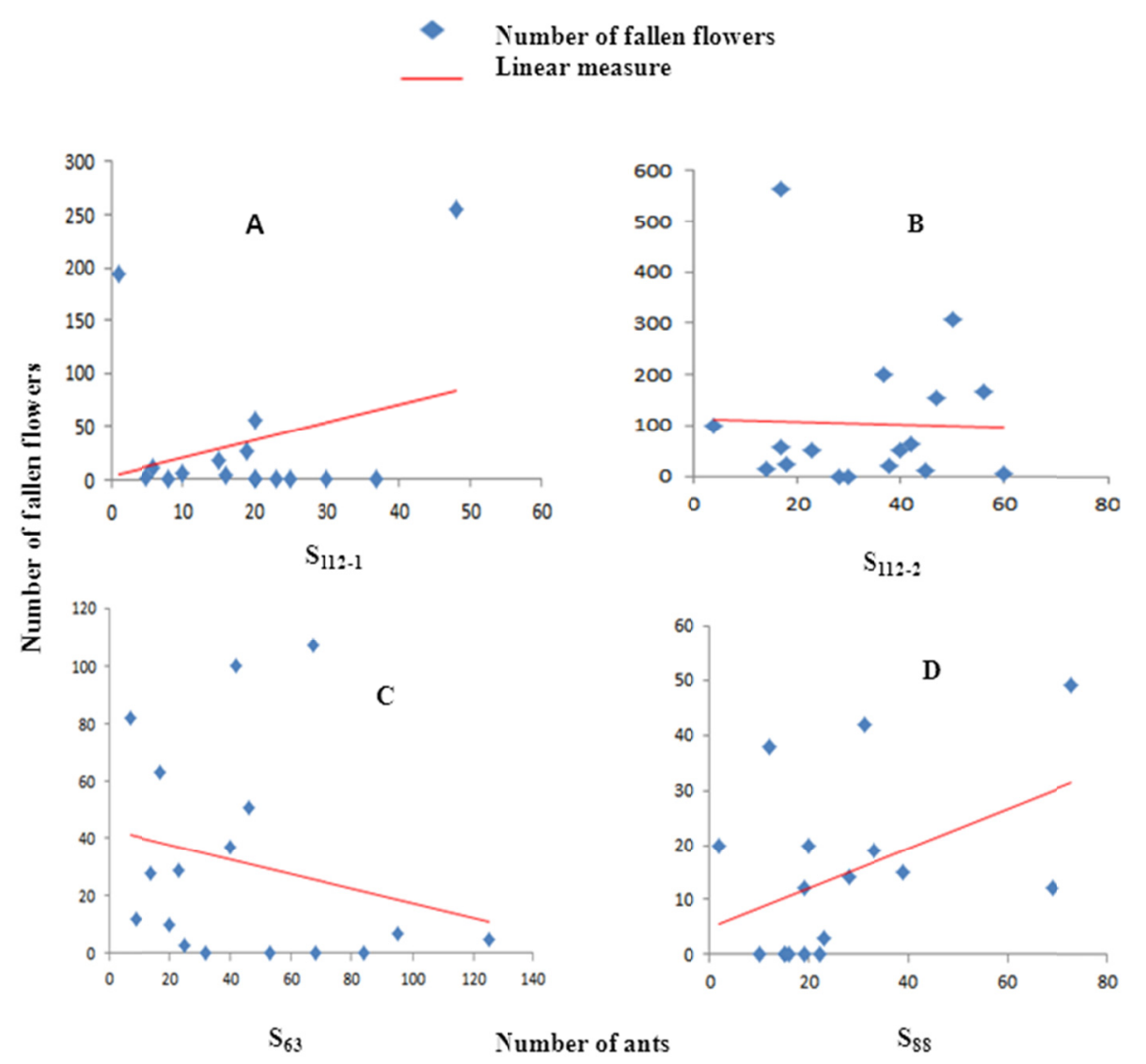

Figure 2. Variation of the number of fallen flowers as a function of the number of ants present in the studied suckers $\left(\mathrm{S}_{112-1}, \mathrm{~S}_{112-2}, \mathrm{~S}_{63}\right.$ and $\left.\mathrm{S}_{88}\right) . \mathrm{A}=$ the case of Phragmantera capitata; $\mathrm{A}, \mathrm{B}$ and $\mathrm{C}$ are cases of T. preussii

\section{Discussion}

Out of the 187 trees recorded in the field, Loranthaceae were found on 44. Foresters present a high rate of parasitism (53\%) compared to cultivated plants. $27 \%$ of Cocoa trees were parasitized while some of their neighboring trees showed no presence of Loranthaceae. This average rate of parasitism obtained on cocoa trees is higher than the one obtained by Ondoua et al. (2016) on cocoa trees in seed fields of Nkoemvone (10.44\%).

Tree species of Loranthaceae are responsible for parasitism in the whole field; P. capitata, T. preussii and T. bangwensis. Among them T. preussii is well represented (64\%) in the agrosystem with a high prevalence on cocoa trees. This species of Loranthaceae was the first to colonize the field. P. capitata is weakly represented (33\%) and mainly attacked fruit trees and foresters of the field. This result doesn't match with Ladoh et al.'s results (2013) in dogbon garden where $P$. capitata was the most abundant and most frequent species on $T$. cacao with a rate of parasitism equal to $59.18 \%$. It has been declared that $P$. capitata is adapted to all ecological areas of Cameroun (Sonke et al., 2000). The species T. bangwensis is weakly represented in the agrosystem with a reduced spectrum of host compared to other Loranthaceae; it was found only on foresters. This was also observed in Ivory Coast by Koffi et al. (2014) were this species colonized different ecological areas. T. bangwensis has also been found on cocoa trees in Ghana with a rate of infestation reaching $70 \%$ (Janny et al., 2003).

Five sub-families distributed into 16 genera and 35 species of ant have been recorded in the whole field. This diversity is higher than those obtained in ndogbon orchad by Dibong (2012), and Ladoh (2011) who respectively found ten and six species belonging to 3 ant subfamilies. According to Djieto-Lordon (2004), ants in agrosystems are not particularly specific to host plants. The ant dominance matches their abundance within Cocoa trees; they are weakly followed by fruit trees. This spatial distribution of myrmecofauna in the agrosystem is due to the fact that trees bearing fruits are known to be more attractive for ants than others. In the same way, infested cocoa trees present a high diversity and abundance compared to healthy ones, due to the presence of Loranthaceae. Plants called myrmecophytes are usually associated to one or more specialized ant species 
(Murase et al., 2002; Djiéto-Lordon et al., 2004). T. aculeatum appeared to be the most dominant ant on T. preussii as well as on P. capitata. It is also the only species found in Loranthaceae. This ant is fond of shady areas, hence is presence in cocoa farms. This is contrary to the results of Mony (2009) in ndogbon orchad where T. aculeatum was not present on cocoa trees. His diet is made of flowers, fruits and so on. So when doing that, the ant provoked the fall of young flowers. But the correlation between ant abundance and the extent of flowers fall was not significant in $P$. capitata sucker $\left(\mathrm{S}_{112-1} ;\right.$ rho $\left.=0.29\right)$ as well as in $T$. preussii suckers respectively $\left(\mathrm{S}_{112-2}\right.$, rho $=0.05 ; \mathrm{S}_{88}$, rho $=0.38 ; \mathrm{S}_{63}$, rho $\left.=0.37\right)$, meaning that the flowers fall is not only the fact of ants, but others parameters intervened. The foraging activity of $T$. aculeatum is diurnal and a complementary activity could be needed to achieve the phenomenon. The foraging activity is mostly observed during flowering and cease when the plant is fruiting. This has already been observed by Ladoh (2013) in Littoral Region.

\section{Conclusion}

The present study carried on at Nkolbisson had as main objectif to determine the myrmecofauna associated to loranthaceae in that field and to see at which extent these ants could be used in biological control against this parasitism. The whole myrmecofauna was distributed into 36 species belonging to 5 sub-families and 15 genus. Their foraging activity was mainly during flowering periods with $T$. aculeatum as the predominant ant species. These ants in general and T. aculeatum particularly contribute to the fall of flowers and fruits by their foraging activity, hence can be used to fight against Loranthaceae. But the level of their result is still poor compared to the extend of damages noticed; Monitoring of feed, ant activity during flowering and fruiting Loranthaceae, show that they participate in the fall of flowers and hence to the reduction of parasitism, but need to be associated with other agents of control in order to improve this biological control against Loranthaceae.

\section{Acknowledgements}

We acknowledge the support of the Department of Zoology of the University of Yaounde I. This work would have been impossible without the support and encouragement of some collegues. We greatly thank Mr Djodo for providing his field for experimentations and collection of ants.

\section{References}

Acheampong, K., Lowor, S., Owusu-Ansah, F., \& Kwabena, O.-A. (2013). Use of Fermented cocoa pulp juice for the control of non-vascular epiphytes on cocoa. Journal of Agricultural and Biological Science, 8(3), 191-195.

Balle, S. (1982). Loranthacées, flore du Cameroun (Vol. 23, p. 82). Cameroun.

Bolton, B. (1994). Identification guide to the ant genera of the world. Harvard University Press, Cambridge.

Bolton, B. (2016). An online catalog of the ants of the word. Retrieved from http://antcant.org

Dibong, S. D., Mony, R., Ndiang, Z., Ondoua, J. M., Boussim, I., JBilong, B., \& Amougou, A. (2010). The struggle against Phragmanthera capitata (Sprengel) S. Balle (Loranthaceae) parasite of agroecosystems' fruit trees in Cameroon. Journal of Agricultural Biotechnology and Sustainable Development, 2(5), 76-81.

Dibong, S. D., Mony, R., Azo'o, J. R. N., Din, N., Boussim Issaka, J., \& Amougou, A. (2012). Myrmecofauna fruit trees infected by Loranthaceae orchards Lokomo (East Cameroun). International Journal of Plant Research, 2(1), 59-63. https://doi.org/10.5923/j.plant.20120201.09

Djiéto-Lordon, C. (2004). Structure des communautés de fourmis arboricoles tropicales Implications évolutives et économiques (p. 221, Thèse de doctorat de l'Université de Toulouse III-Paul Sabatier).

Djiéto-Lordon, C., Dejean, A., Gibernau, M., Hossaert-Mc Key, M., \& Mc Key, D. (2004). Symbiotic mutualism with a community of opportunistic ants: Protection, competition, and ant occupancy of the myrmecophyte Barteria nigritana (Passifloraceae). Acta Oecologica, 26, 109-116. https://doi.org/10.1016/j.actao.2004. 03.007

Hölldobler, B., \& Wilson, E. O. (1990). The ants (p. 732). The Belknap Press of Harvest University: Cambridge, Massachusetts. https://doi.org/10.1007/978-3-662-10306-7

Janny, G. M. Vos, B. J. R., \& Flood, J. (2003). A la découverte du cacao: Un Guide pour la formation des facilitateurs (p. 115). CABI Bioscience.

Koffi, A. A., Kouassi, A. F., N'goran, K. S. B., \& Soro, D. (2014). Les Loranthaceae, parasites des arbres et arbustes: Cas du département de Katiola, au nord de la Côte d'Ivoire. International Journal of Biological and Chemical Sciences, 8(6), 2552-2559. https://doi.org/10.4314/ijbcs.v8i6.17 
Ladoh Yemeda, Mony, R., Tchatat, M., \& Dibong, S. (2013). Contribution des fourmis à la lutte biologique contre les Loranthaceae. International Journal of Biological and Chemical Sciences, 7(3), 924-937. https://doi.org/10.4314/ijbcs.v7i3.4

Ladoh Yemeda, C. F. (2011). Parasitisme par les Loranthaceae et myrmécofaune associée aux plantes ligneuses dans un verger à Ndogbong (douala) Mémoire de D.E.A., Université de Douala.

Mony, R., Ondoua, J. M., Dibong, S. D., Boussim, I. J., Amougou, A., \& Billong, B. (2009). Myrmécofaune arboricole associée aux couples Phragmanthera capitata (Sprengel) S. Balle/hôte au verger de la chefferie de Ndogbong. Journal of Biological and Chemical Sciences, 3, 1346-1356.

Murase, K., Itioka, T., Inui, Y., \& Itino T. (2002). Species specificity in settling-plant selection by foundress ant queens in Macaranga-Crematogaster myrmecophytism in a Bornean dipterocarp forest. Journal of Ethology, 20, 19-24. https://doi.org/10.1007/s10164-002-0049-8

Neumann, U., \& Sallé, G. (2003). Mécanismes de defense des plantes contre les angiospermes parasites. Centre de Recherche Agriculture France, 86(8), 85-96.

Olivry, J. C. (1986). Fleuves et rivières du Cameroun (p. 781). Paris: MESRES-ORSTOM.

Ondoua, J. M., Mony, R., Dibong, S. D., Ngotta Biyon, J. B., Taffouo, V. D., Kenne, M., \& Ekodeck, G. E. (2016). Myrmecofauna of cocoa trees infested by Loranthaceae genus Phragmanthera in Sodecao seed fields of Nkoemvone (South of Cameroon). Journal of Entomology and Nematology, 8(3), 19-27. https://doi.org/10.5897/JEN2016.0154

Polhill, R., \& Wiens, D. W. (1998). Misteltoes of Africa (p. 370). The Royal Botanic Kew (New Ed.)

Sonké, B., Kenfack, D., \& Tinto M. (2000). Parasitisme de l'avocatier (Persea americana, Lauraceae) par les Loranthacées dans la région de Yaoundé (Cameroun) Fruits, 55, 325-331.

Taylor, B. (2011). The ants of West Africa and the Congo Basin. Retrieved from http://www.antbase.org/ ants/africa/antcocver.htm

\section{Copyrights}

Copyright for this article is retained by the author(s), with first publication rights granted to the journal.

This is an open-access article distributed under the terms and conditions of the Creative Commons Attribution license (http://creativecommons.org/licenses/by/4.0/). 